\title{
Electromagnetic Fields Exposure From Extra High Voltage Transmission On Public Health: A Case-Control Study in Three Districts In Central Java
}

\author{
Anies $^{1}$, Dwi P. Sasongko² \& Retno Setyowati ${ }^{3}$ \\ ${ }^{1}$ Public Health Science Study Program, Faculty of Medicine, Diponegoro University, Semarang, Indonesia \\ ${ }^{2}$ Department of Physics, Faculty of Science and Mathematics, Diponegoro University, Semarang, Indonesia \\ ${ }^{3}$ Doctoral Program in Human Resource Management, Faculty of Economics and Business, Diponegoro University, \\ Semarang, Indonesia \\ Correspondence: Anies, Public Health Science Study Program, Faculty of Medicine, Diponegoro University, \\ Semarang 50275, Indonesia. Tel: 622-47-460-044. E-mail: profanies@ymail.com
}

Received: May 14, 2018 Accepted: August 8, 2018 Online Published: August 11, 2018

doi:10.5539/gjhs.v10n9p54 URL: https://doi.org/10.5539/gjhs.v10n9p54

\begin{abstract}
This study is to prove the effect of electromagnetic field exposure from $500 \mathrm{kV}$ Extra High Voltage Transmission to the incidence of electrical sensitivity and the extent of the risk of electrical sensitivity incidence on the population residing in areas/in the proximity of $500 \mathrm{kV}$ transmission facilities compared to residents who do not live under it. The study design employed is the case-control observational analytic epidemiology, and qualitative study, with 249 samples, consisted of 83 cases and 166 controls. The study was conducted in Pekalongan municipality, Pemalang municipality and Tegal municipality, all in Central Java. The results show that there are some effects of the electromagnetic field $500 \mathrm{kV}$ electricity transmission exposure with the incidence of electrical sensitivity. Moreover, the electrical sensitivity incidence on the residents living under $500 \mathrm{kV}$ electricity transmission is 5.8 times compared to those who do not live under $500 \mathrm{kV}$ electricity transmission.
\end{abstract}

Keywords: electromagnetic fields (EMF) exposure, extra high voltage transmission, electrical sensitivity, public health.

\section{Introduction}

Electricity needs in daily life, both in the household, office and industry, increasing from year to year. Even in recent years, the need for electric power for industry has very rapidly increased. The increase in demand is offset by the construction of power plants, both government and private. The power from the power station is initially channeled to the main substations, for then from the substation to be distributed to households, offices, industries and other places that need it. Distribution of electricity from the power plant to the substations and from one substation to the other substations requires a transmission network known as the High Voltage Transmission (HVT) and an Extra High Voltage Transmission (EHVT). HVT is a power line that uses bare wire in air-voltage $150 \mathrm{kV}$, while the EHVT is a power line that uses bare wire (conductor) in air-voltage above $245 \mathrm{kV}$ according to the standard in the field of power-electricity. In Indonesia, the EHVT operates at $500 \mathrm{kV}$ (Indonesian Ministry of Mining and Energy, 1992).

Health problems, however, arise along with EHVT development which often passes through residential areas. Some research noted that the development of EHVT can cause health problems to the surrounding population. This paper, hence, would like to analyze the effect of EHVT on the public health, especially those living benath it. There are several problems related to the effect of electromagnetic field exposure of $500 \mathrm{kV}$ EHVT on the health of the population, especially those living under the $500 \mathrm{kV}$ EHVT. Further detail, the questions are (1) is there a complaint or health problem in the population under $500 \mathrm{kV}$ EHVT and (2) what health complaints or disorders commonly experienced by residents who live under the $500 \mathrm{kV}$ EHVT. Furthermore, (3) what is the effect of exposure to electromagnetic fields other than $500 \mathrm{kV}$ EHVT on the occurrence of complaints or health problems and (4) is there any effect of electromagnetic field exposure $500 \mathrm{kV}$ EHVT with electrical sensitivity event. In addition, (5) is there any effect of the use of electrical equipment by residents who live under $500 \mathrm{kV}$ EHVT with electrical sensitivity events and (6) is there any influence of the work of the people who use electrical equipment 
with electrical sensitivity events. Lastly, (7) is there any influence of population activity residing under $500 \mathrm{kV}$ EHVT with electrical sensitivity occurrence. These questions prove that the problems of electromagnetic field exposure of $500 \mathrm{kV}$ EHVT on population health are very complex, or at least needs much more in-depth investigation. Health problems in humans are very wide and many kinds, because it involves various systems and organs. However, the health disorder to be studied is limited to the effect of electromagnetic field exposure of 500 $\mathrm{kV}$ EHVT on the occurrence of a set of symptoms known as electrical sensitivity. Therefore, the researcher limits this research problem to is there any effect of electromagnetic field exposure $500 \mathrm{kV}$ EHVT on the occurrence of electrical sensitivity?. Specifically, the problems of this research are formulated as follows: (1) is there any effect of electromagnetic field exposure $500 \mathrm{kV}$ EHVT to the occurrence of electrical sensitivity? (2) what is the risk of electrical sensitivity in the population living in areas/in the proximity of 500kV EHVT facilities compared to those that are not living under this electromagnetic transmission?

\section{Literature Review}

The construction of EHVT was initially attempted to pass through areas outside the residential area. The construction of $500 \mathrm{kV}$ EHVT continues to grow, causing the $500 \mathrm{kV}$ EHVT is often forced to pass through residential areas or areas around the settlement. The establishment of EHVT has long caused concern among the surrounding population because of the possible negative influence of electromagnetic fields produced by $500 \mathrm{kV}$ EHVT on their health. The empirical evidences from scholarly publications of several studies on the influence of electromagnetic fields on health to date is inconclusive (Anies, 1997; Kumar, Behari, \& Sisodia, 2013; Singh \& Kapoor, 2014; Maziarz et al., 2016). The publication of the results of a study conducted by Wertheimer and Leeper (1979) in the United States, illustrates an association of increased risk of death from blood cancer (leukemia) in children with distance from their home network high-voltage electrical transmission. However, the results of these studies (Wertheimer \& Leeper, 1979; Anies, 1997; Kumar et al., 2013; Singh \& Kapoor, 2014; Maziarz et al., 2016) are considered to have weaknesses, in the absence of data measuring the electric field strength and magnetic field strength received by the group of children studied. Corrections to the study by Savitz, Pearce and Poole. (1993) and London et al. (1991), suggest that the relationship was not proven. Several studies (Kumar et al., 2013; Hanc1 et al., 2013; Hao et al., 2013; Zhang, Liu, Zhang, \& Li, 2015) using experimental animals have also been conducted since the sixties and the results are still varied, ranging from no-effect images, no effect on behavioral changes until the occurrence of defects in the offspring. Although the results of examination of the effect of electromagnetic exposures on animal indicate the presence of adverse effects, such exposures effect does not prove harmful in residential, working environments and human health (World Health Organisation [WHO], 1987).

In the last three decades, there have been various studies on the impact of electromagnetic fields on human health. Reiter reports that electromagnetic field exposure can affect the metabolism of the hormone melatonin (N-acetyl-5-methoxy-triptamine) produced by the pineal gland, located between the two sides of the brain (Kato, Honma, Shigemitsu, \& Shiga, 1994). This hormone serves to suppress the incidence of cancer, especially breast cancer. The low production of the hormone melatonin can pose a risk of breast cancer (Reiter, 1997). Increased levels of the hormone melatonin can increase prolactin levels, cause breast enlargement and decrease sexual ability (Esquifino et al., 1989). In addition, the hormone melatonin regulates the circadian rhythm or the rhythm of wake and sleep, so that low levels of melatonin can cause sleeplessness (Graham et al., 1997; Zordan \& Kyriacou, 2005). Linet et al. (1997) reported the results of the study in 1258 children, who examined the association between the occurrence of lymphoblastic leukemia cancer and the exposure of the EHVT electromagnetic field. This study showed no association between the occurrence of acute lymphoblastic leukemia in children and the possible exposures from EHVT electromagnetic fields through their residence. Kleinerman (2000) indicates the exposure to electromagnetic fields derived from EHVT may result in lymphoblastic leukemia in children. Jonai, Villanueva and Yasuda (1996) exposed to peripheral blood mononuclear cells with electromagnetic fields of $1 \mathrm{mT}, 3 \mathrm{mT}, 10$ $\mathrm{mT}$ and $30 \mathrm{mT}$ for 3 days. The likelihood of cancer by electromagnetic fields is investigated by measuring cytokine production. Through exposure to the intensity of 100 times the intensity of the exposure limit in the general public, it is only seen a change in cytokine levels. This study proves that electromagnetic field exposure as found in the community is not an initiator of cancer.

However, there is a little empirical study on the influence of electromagnetic field exposure to human health that was done in Indonesia. One such research is a collaboration between Institute of Community Service of Bandung Institute of Technology and Faculty of Medicine University of Indonesia on the influence of electric field and magnetic field $500 \mathrm{kV}$ EHVT to health of the population in Bekasi, West Java in 1996. The research design used wass epidemiological studies with cross-sectional approach and was conducted by examination in 1228 sample, which includes physical examination, blood laboratory, EKG, EEG, as well as assessment of mental disorders. This study found that $11 \%$ of respondents experienced abnormalities in physical examination and $10.2 \%$ of 
respondents experienced laboratory abnormalities. However, the abnormality that occurs has no correlation with the exposure of the electric field and magnetic field derived from the $500 \mathrm{kV}$ EHVT (LPM-ITB \& FKUI, 1997). Research on the perception and habits of the population in relation to the $500 \mathrm{kV}$ EHVT has also been done by Kasnodihardjo and his colleagues from the Health Research Ecology Center of the Health Research and Development Agency of the Ministry of Health, in Cibinong and Bekasi, West Java. The results show that the concerns that arise among the population in general is not related to health issues, but rather more about socio-economic aspects. The presence of $500 \mathrm{kV}$ EHVT that passes in the settlement raises concerns among the population that the economic value of assets they own in the form of land, whether occupied or productive land as a source of life will decrease because of the few people who want to buy land around EHVT (Kasnodihardjo, 1998). Findings from Anies' (1999) study on the effects of $500 \mathrm{kV}$ EHVT electromagnetic exposure on the public health in South Bandung, Ungaran, and in other regencies on the northern coast of Central Java such as Pekalongan, Pemalang and Tegal Regencies showed that residents living around $500 \mathrm{kV}$ EHVT complained of pounding, sleep difficulties and headaches, and had concerns about damaged cable accidents (Anies, 1999; Kurniawan, 2017). One of the effects of $50 / 60 \mathrm{~Hz}$ frequency electromagnetic field on health is known as electrical sensitivity, such as headache, dizziness, sleep disturbance, fatigue chronic fatigue syndrome and pounding (Grant, 1997; Grant, 2003).

\section{Electromagnetic Fields Exposure of Extra High Voltage Transmission (EHVT) and the Public Health}

Electromagnetic fields, electric fields and magnetic fields, have existed since the beginning of the earth and the universe was created, known as the electric field and the earth's magnetic field. Today's life is difficult to separate from electricity, because almost all household appliances, offices, industries and means of communication use electricity. The growing need for electric power demands the construction of power plants along with transmission lines to distribute them to the main substations and from one substation to another, known as the $150 \mathrm{kV}$ High Voltage Transmission (HVT) and the $500 \mathrm{kV}$ Extra High Voltage Transmission (EHVT). $500 \mathrm{kV}$ EHVT over time is growing. In the past, the available land was still large enough, so the power transmission lines, including the 500 $\mathrm{kV}$ EHVT, were still passing through the open space. But now the amount of available land is very limited and narrow, due to the rapid development of housing and industry. Hence, more and more $500 \mathrm{kV}$ EHVT pass through residential areas. $500 \mathrm{kV}$ EHVT will produce an electromagnetic field which among others will cause exposure to humans who live under it. The current flowing on a conductive object such as in humans due to the exposure of the electromagnetic fields, is determined by the field strength, frequency and shape or magnitude of the object. The closer the human to the source of the exposure, the higher the exposure it receives. Electromagnetic field exposure is not only derived from $500 \mathrm{kV}$ EHVT. The use of various electronic appliances in households, offices, industries and so on, also raises the exposure of electromagnetic fields. Exposure to electromagnetic fields $500 \mathrm{kV}$ EHVT is a risk factor for the occurrence of health problems, such as system and body disorders, among others (Anies, 1997; Anies, 1999): (1) blood system, (2) reproduction system, (3) nervous system, (4) cardiovascular system, (5) endocrine system, (6) psychological, and (7) hypersensitivity. The manifestation of hypersensitivity is known as electrical hypersensitivity or electrical sensitivity. This term describes the physiological disorders of neurological indicators and symptoms as well as sensitivity to electromagnetic fields. Symptoms showing electrical sensitivity include headache, dizziness, and fatigue. Other indicators and symptoms that can be found, such as cardiac palpitations, sleep disturbance, difficulty in concentrating, nausea and digestive problems are unclear, ringing ears (tinnitus), facial burning and rashes, muscle spasms, confusion, and psychiatric disorders such as depression. Not every person exposed to electromagnetic fields will complaint, have symptoms, cause disease or impaired function of organs. While the manifestation of complaints, symptoms, diseases or disorders of organs function very varied. Similarly, the disturbance of electrical sensitivity is not likely to have similar effect between one and another with the same complaint. Likewise, the variation of complaints between one person and another is not always the same, depending on the sensitivity of the function and the organs of the person concerned. In the preliminary study, the most common electrical sensitivity variation was the combination of headache, dizziness and chronic fatigue syndrome. Based on the above description, it is suspected that there is an effect of electromagnetic field exposure of $500 \mathrm{kV}$ EHVT to the publich health, in this case in the form of electrical sensitivity. This study also proposes initial assumption that the risk of electrical sensitivity to residents living under EHVT of $500 \mathrm{kV}$ is higher than the population do not reside under $500 \mathrm{kV}$ EHVT.

\section{Hypothesis Formulation}

The hypothesis of this research is formulated as follows: (1) There is an effect of electromagnetic field exposure of $500 \mathrm{kV}$ EHVT to the occurrence of electrical sensitivity (2) The risk of electrical sensitivity in the population residing under $500 \mathrm{kV}$ EHVT is higher than the non-resident population under $500 \mathrm{kV}$ EHVT. 


\section{Research Methodology}

\subsection{Research Purpose}

This study aims to determine the effect of $500 \mathrm{kV}$ EHVT electromagnetic field on the health of the population under, as well as the magnitude of the risk of electrical sensitivity in residents who live under $500 \mathrm{kV}$ EHVT compared with residents who do not reside under $500 \mathrm{kV}$ EHVT.

\subsection{Research Design}

To obtain a more in-depth answer on the substance studied, a qualitative explorative approach design is used. The method used in this study was a combination of epidemiological studies of case-control and qualitative observational of several factors considered important.

\subsection{Research Location}

The research was conducted in Pekalongan Regency, Pemalang Regency and Tegal Regency, all in Central Java.

\subsection{Data Collection}

Data were collected using instrument: (1) metveer, a tool to measure the distance of home exposure to $500 \mathrm{kV}$ EHVT, (2) standard instrument in the form of guidance to determine exposure to electronic equipment, and history to diagnose electrical sensitivity event, (3) stethoscope, tensimeter and Sahli haemometer which have been calibrated to determine exclusion criteria, (4) in-depth interviews, to explore the exposure of $500 \mathrm{kV}$ EHVT and electrical sensitivity complaints.

\subsection{Sampling}

The sample size in a retrospective analytic study was determined by the following factors:

- Estimated rate of exposure in the community

- Level of Relative Risk measure (R) that is considered to have clinical significance

- The degree of trust used in the analysis, expressed by the symbol $\alpha$

- The degree of sensitivity of statistical tests is expressed by the symbol $\beta$

$$
n=\frac{[Z \alpha \sqrt{2 u(1-u)}+Z \beta \sqrt{f(1-f)+p q}]^{2}}{(f-p)^{2}}
$$

In which:

$$
u=\frac{\frac{1}{2} f(1+R)}{1+f(R-1)} \quad q=1-p \quad p=\frac{f R}{1+f(R-1)}
$$

$\mathrm{f}=$ Exposure level of the causative factor in the population

$\mathrm{R}=$ Relative Risk

$Z \alpha=$ Relative deviation for $\alpha$ level

$\mathrm{Z} \beta=$ Relative deviation for $\beta$ level

$\mathrm{n}=$ sample size

$q=$ proportion of unexposed population

$p=$ proportion of exposed population

$u=$ limit of error

The sample size in this study was determined with significance level $(\alpha)=0.05$, and statistical sensitivity $(\beta)=0.20$. Furthermore, the sample was determined by $10 \%$ population living under $500 \mathrm{kV}$ EHVT facilities with relative risk of 3 times. With this determination, it was obtained a sample size of at least 83 cases. In this study, case and control comparisons were made 1:2, so the controls were 166. Thus, the number of samples (cases and controls) was 249. The selected samples, for cases and controls, are based on inclusion and exclusion criteria as follows:

(1) Inclusion Criteria

a. Minimum age of 14 years old 
b. The sample resides under the $500 \mathrm{kV}$ EHVT or at most 25 meters lateral to the $500 \mathrm{kV}$ EHVT location.

(2) Exclusion Criteria

a. They are suffering from anemia, hypertension, hypotension or chronic disease

b. Working as well as using electrical equipment in daily activities.

The variables of this study consist of independent variables, namely electromagnetic field $500 \mathrm{kV}$ EHVT, and the dependent variable, that is electrical sensitivity. The research procedure begins by establishing case groups, control groups, sample size, observation and analysis with estimated relative risk (odds ratio).

\subsection{Analytical Study of Observational Case-Control}

In a case-control study, the incidence rate can not be calculated, so it is only considered a relative risk estimate, or called the Odd's Ratio (OR). Practically, it can be illustrated in the following 2x2 Case-Control table (Table 1).

Table 1. Case-Control 2 × 2

\begin{tabular}{lllll}
\hline & & \multicolumn{2}{c}{ Effect } & Total \\
\cline { 3 - 5 } & & + & - & \\
\hline \multirow{3}{*}{ Risk Factor } & + & $\mathrm{a}$ & $\mathrm{b}$ & $\mathrm{a}+\mathrm{b}$ \\
& - & $\mathrm{c}$ & $\mathrm{d}$ & $\mathrm{c}+\mathrm{d}$ \\
& Total & $\mathrm{a}+\mathrm{c}$ & $\mathrm{b}+\mathrm{d}$ & $\mathrm{a}+\mathrm{b}+\mathrm{c}+\mathrm{d}$ \\
\hline
\end{tabular}

Table 1 (case-control $2 \times 2$ ) shows the results of observation in case study control:

Cell a $=$ Effect $(+)$, Risk factor $(+)$

Cell $b=$ Effect $(-)$, Risk factor $(+)$

Cell c $=$ Effect $(+)$, Risk factor $(-)$

Cell $\mathrm{d}=$ Effects (-), Risk factor (-)

The case groups exposed to the risk factors studied were the cases of a, and those, which were not exposed, representing cases $\mathrm{c}$. While among the control group, the control group exposed to the risk factors was $\mathrm{b}$ and the unexposed was $\mathrm{d}$. Therefore, the odd's value for the case group is a/c, whereas the odd's value for the control group is b/d. Based on the above definition, 'OR' case group compared to the control group is formulated into (a/c): (b/d).

The value of $\mathrm{OR}>1$ is significant, independent variable as the cause factor of the dependent variable.

The value of $\mathrm{OR}=1$, there is no association.

The value of $\mathrm{OR}<1$ is significant, the independent variable as the preventing factor of the dependent variable.

\subsection{Qualitative Data Analysis}

To increase the credibility of results, this study also conducts the informant studies, in which informants who become respondents in this study are the people who really know about the variable studied, that are the electromagnetic exposures of $500 \mathrm{kV}$ EHVT and its effect on public health. Informants are from exposed or resident residents under the $500 \mathrm{kV}$ EHVT, community leaders and sources who know exactly technically about $500 \mathrm{kV}$ EHVT and reside in the exposure area. The data from the informants are all obtained through in-depth interviews. Moreover, triangulation is done to test the validity of the data obtained. In this research, triangulation used is source triangulation, that is by comparing and doing data contrast.

\subsection{Preliminary Study}

To know the existence of electrical sensitivity on the population who live under $500 \mathrm{kV}$ EHVT, the researcher conducted preliminary study on the population in Kecamatan Kedungwuni, Pekalongan Regency. Respondents are residents who meet the inclusion criteria: (1) at least 14 years of age and (2) residing under the $500 \mathrm{kV}$ or at most 25 meters lateral from the $500 \mathrm{kV}$ EHVT. Data were collected based on interviews, physical examination, laboratory examination and diagnosis by doctors. Respondents who met the inclusion criteria were 114. The most common health problem (32.5\%) was a series of three symptoms, namely headache, dizziness and chronic fatigue, while those without complaints were only $16.7 \%$. Based on the preliminary study, the next step done is electrical triangulation sensitivity that is electrical sensitivity in the form of headache, dizziness and chronic fatigue 
syndrome.

\section{Results}

\subsection{Characteristics of Respondents}

The research was conducted in three districts in Central Java that were crossed by $500 \mathrm{kV}$ EHVT, namely Pekalongan Regency, Pemalang Regency and Tegal Regency. In general the condition of the three research areas is the same, having much agricultural and plantation areas around the plateau. The livelihood of the population is generally farmers. However, the diminishing rice fields cause many people who cannot afford the living needs of the agricultural sector and some young people are looking for jobs in big cities. Some samples have non-agricultural jobs originating from the existence of textile, confection and batik businesses in their area. This type of sample can be found, for example in Ambokembang, Kedungwuni District, Pekalongan Regency, with many residents working as textile and confection laborers. Of the total 249 respondents, 185 were women, while men were as much as 94 . Most respondents were in age group 31-50 years old $(51.7 \%)$ and the smallest age group was above 50 years (20\%). This study measured two variables, namely electromagnetic field $500 \mathrm{kV}$ EHVT and electrical sensitivity, conducted on 249 respondents. Respondents consisted of cases and controls. The case is electrical sensitivity (ES +) and the control is not electrical sensitivity (ES-). While the electromagnetic field exposure of $500 \mathrm{kV}$ EHVT consists of criteria inside exposure and outside exposure. A total of 171 samples was inside the exposure, and the other (78 residents) was outside of the $500 \mathrm{kV}$ EHVT exposure.

The principle in this case-control study begins with finding a number of cases based on the sample size calculation and followed by the determination of the control according to the ratio between case and control. Based on the inclusion and exclusion criteria, 432 respondents were obtained, consisting of 159 cases and 273 controls. All respondents who met the inclusion and exclusion criteria living under $500 \mathrm{kV}$ EHVT to 25 meters lateral from the $500 \mathrm{kV}$ EHVT were referred to as exposed respondents. Non-exposure respondents were all residents who met the inclusion and exclusion criteria, spaced more than 25 meters laterally from $500 \mathrm{kV}$ EHVT and still within the administrative area of RW or dukuh. Respondents in the $500 \mathrm{kV}$ EHVT exposure were 272 respondents, while those outside the exposure were 260 respondents. Based on the large sample calculations for retrospective studies, the number of cases group is 83 respondents and the 166 respondents for control group. After simple random sampling, the following results are obtained (Table 2).

Table 2. Case and Control Distribution

\begin{tabular}{lllll}
\hline & & Effect & \\
\cline { 3 - 4 } & & + & - & Amount \\
\hline \multirow{2}{*}{ Risk Factor } & + & $\mathbf{a}(74)$ & $\mathbf{b}(97)$ & 171 \\
& - & $\mathbf{c}(9)$ & $\mathbf{d}(69)$ & 78 \\
& Amount & 83 & 166 & 249 \\
\hline
\end{tabular}

The exposed respondents with ES+ were as much as 74 respondents, as shown in cell a. Furthermore, exposed respondents with ES- were as much as 97 respondents as indicated by cell b. Moreover, cell c shows that the unexposed respondent with ES + were 9 respondents, while cell d shows that the unexposed respondents with ESwere as much as 69 respondents. Then, the case is cell $\mathrm{a}+\mathrm{cell} \mathrm{c}$, while control is cell $\mathrm{b}+\mathrm{cell} \mathrm{d}$, as stated in pie chart Figure 1. 


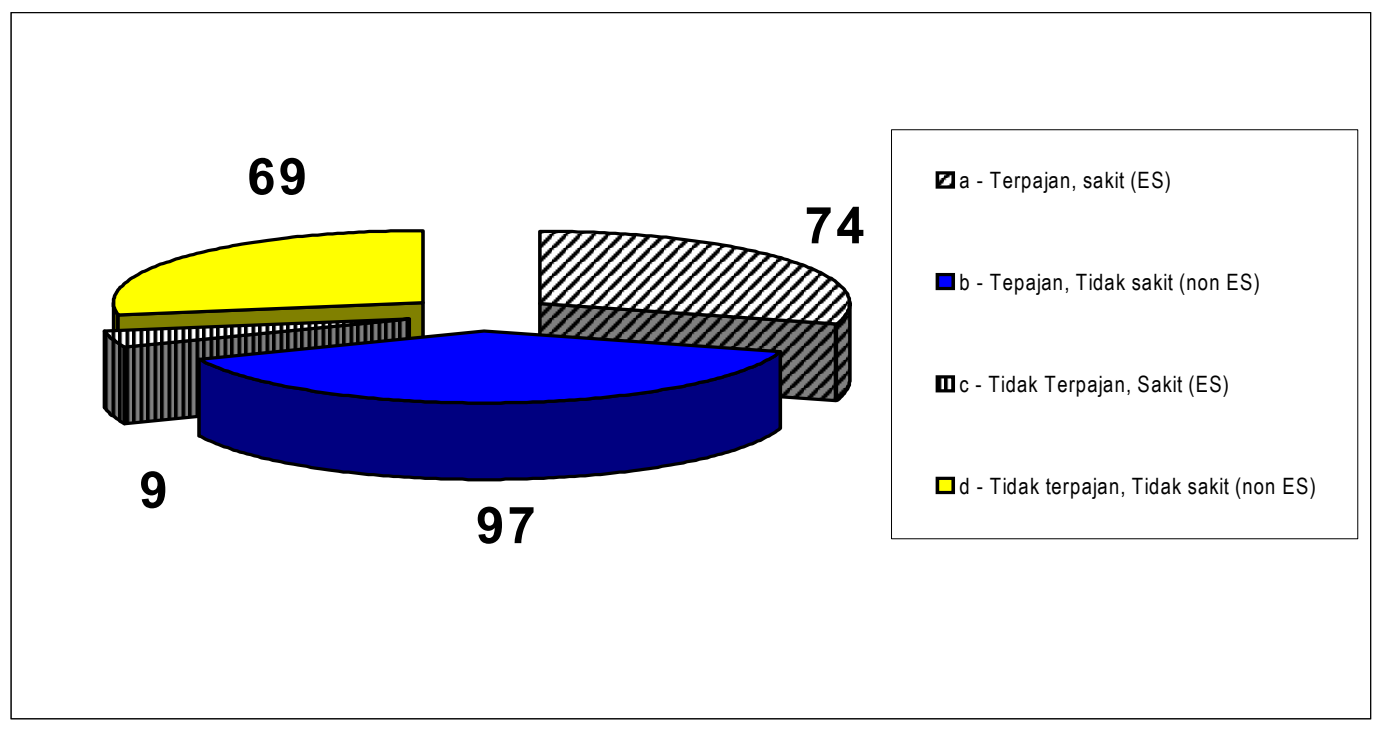

Figure 1. Case and Control Distribution

\subsection{Requirements Analysis Testing}

To test the hypothesis through case-control needs some requirements to be met. The first is that there should be a statistical association between the electromagnetic field exposure of $500 \mathrm{kV}$ EHVT and electrical sensitivity, using Chi-Square Test. Moreover, after conducting the test of Chi-Square Test, the results show a significant relationship between electromagnetic field exposure $500 \mathrm{kV}$ EHVT with electrical sensitivity (X2 $=22,871 ; \mathrm{p}<0.001)$. Thus, the hypothesis through case-control can be done in further step.

\subsection{Hypothesis Testing}

Hypothesis testing is intended to find out whether (1) there is an effect of electromagnetic field exposure of $500 \mathrm{kV}$ EHVT on the occurrence of electrical sensitivity and (2) the magnitude of the occurrence of electrical sensitivity in the population living in areas/in the proximity of 500kV EHVT facilities is higher than those who do not live under $500 \mathrm{kV}$ EHVT. In the retrospective study design, the insidence rate is unknown, as the new case is mixed with the old case, so the estimated relative risk is asserted by the Odd's Ratio (OR). Found OR $=5,849$ (95\% CI: 2,742 $12,477)$, so the risk of electrical sensitivity in residents living under EHVT of $500 \mathrm{kV}$ is 5.8 times that of those who are not living under $500 \mathrm{kV}$ EHVT.

\section{Discussion}

The result of hypothesis testing shows that the greatest risk of the population exposed to electromagnetic field 500 $\mathrm{kV}$ EHVT to get a health problem in the form of electrical sensitivity is 5.8 times higher than the unexposed population. This is in accordance with the statement of Grant (1997) and Real et al. (1991), that electromagnetic fields can generate hypersensitivity in the form of electrical sensitivity, with symptoms and indicators such as headache, dizziness and chronic fatigue syndrome, which are the findings of this study and is known as "trias electrical sensitivity" (Grant, 1997; Real et al., 1991). As stated by Mueller, Krueger and Schierz (2002), the exposure of electromagnetic fields can have an effect on health as the triggers of headache symptoms. In addition, the electromagnetic fields generated by high-voltage transmission networks can cause headache complaints and depression (Poole et al., 1993). Electromagnetic field exposure is not only derived from $500 \mathrm{kV}$ EHVT alone, but can come from electronic appliances in the household, office or industry. In modern life, electromagnetic radiation of radio waves is easy to find. The use of cell phones as an important means of communication and microwave ovens that greatly assist the work in the kitchen, is an example of such radio wave electromagnetic radiation sources and can cause a variety of complaints such as headaches and fatigue for no apparent reason (Arber, 1985). The potential for radiation is higher, considering the use of cell phones has been so widespread in the community. In addition, radio transmitters also have the potential to cause radio-frequency electromagnetic radiation, which has been largely ignored by most people, including workers in the field of radio communications. As Sandström, Wilen, Hansson Mild and Oftedal (2001) points out, the use of cell phones can also cause headache complaints. Oftedal, Wilen, Sandström and Mild (2000) also pointed out that complaints of headaches and dizziness can be caused by electromagnetic field sensations, especially electromagnetic radio waves. A similar opinion is expressed 
by Adey et al. (1997) and Lai (1994) that the exposure of radio wave electromagnetic fields can have an impact on public health, both on the job and on daily activities. Frey (1998) even mentioned that the emergence of headache complaints are often found in the mobile phone users.

However, in this study, the possibility that these complaints came from the use of electronic equipment could be removed. This is because the use of electronic equipment at home is an exclusion criterion for respondents in this study. The existence of these symptoms is considered a symptom of hypersensitivity to electromagnetic fields of $500 \mathrm{kV}$ EHVT, not from electronic equipment in households, industries and communication equipment such as cellphones or other communication equipment, which have very low electromagnetic exposures and are not considered harmful to health (WHO, 2007). The International Radiation Protection Association also identified that one of the health problems caused by electromagnetic field exposure of $500 \mathrm{kV}$ EHVT was hypersensitivity (International Non-ionizing Radiation Committee of the International Radiation Protection Association, 1990). Here is an illustration of the use of electrical equipment by DM, a respondent, housewife.

"I do not use electric appliance, sir. Here I only use 150 watts of electricity just enough for home lighting, less bright."

Similarly, SN, a tailor, said:

"I never use electrical appliances, two sewing machines for work with a swivel by hand."

Statements by both respondents illustrate that they are not exposed to electromagnetic fields derived from electronic equipment, because they do not use them in daily activities. $500 \mathrm{kV}$ EHVT can affect the socio-cultural population under, the perception of the existence of the $500 \mathrm{kV}$ EHVT (International Radiation Protection Association, 1990; Tumiran, 2005). Research conducted by Kasnodihardjo (1998) and friends about the perceptions and customs of the population in relation to the presence of $500 \mathrm{kV}$ EHVT in Cibinong and Bekasi, West Java shows that the fear and concern that arise among the population is not about health problems. The presence of $500 \mathrm{kV}$ EHVT raises concerns that the economic value of their land is reduced. Concerning the fears and anxieties resulting from perceptions of the presence of $500 \mathrm{kV}$ EHVT which could cause a health disorder of respondents, $\mathrm{BCH}$, a public figure, responses:

"You said that after studying in this village living under EHVT is dangerous. But I do not feel anything."

Similarly, some residents living under $500 \mathrm{kV}$ EHVT, as IR, a carpenter, said:

"I have never been afraid or anxious under EHVT. If it hurt maybe yes, because the condition of the body down, not because of EHVT."

The cause of headache complaints, dizziness and chronic fatigue is complex and multifactorial, because it can accompany various diseases. This set of symptoms can be due to organic or psychological causes. The latest theories about melatonin hormone metabolism and its effect on the emergence of various symptoms and mood swings, are expected to explain why electromagnetic field exposures can cause these symptoms (Sandyk \& Derpapas, 1993). The hormone melatonin (N-acetyl-5-metoksitriptamin) is a hormone secreted by the pineal gland, a gland the size of a peanut that lies between the two sides of the brain. The hormone melatonin in the body regulates circadian rhythms, so people sleep at night and wake up in the morning (Lewy, Ahmed, Jackson and Sack (1992). Production of the hormone melatonin can be driven by dark and silent and inhibited by bright light and electromagnetic fields (Zhdanova et al 1995). These symptoms are related to changes in the metabolism of the hormone melatonin produced by the pineal gland. These symptoms primarily arise when the production of the hormone melatonin is reduced (Dollins et al, 1994). Production of the hormone melatonin increases during the night, especially in the atmosphere of silence and dark, causing people to sleep easily. However, the production of this hormone is reduced by the presence of external stimuli, such as light and electromagnetic fields (National Sleep Foundation, 2004). As Hawkins (1992) points out, the light and exposure of the electromagnetic field can decrease the production of the hormone melatonin and potentially cause a variety of complaints including headache, dizziness and fatigue. Even, an identification of melatonin levels could lead to symptoms of "jet lag," such as someone who has taken an old flight, including fatigue and headaches, and nausea and irritability (Petrie, Dawson, Thompson \& Brook, 1993). Although electromagnetic field exposure originating from $500 \mathrm{kV}$ EHVT is not the only cause of melatonin hormone loss, but considering the exposure of other electromagnetic fields to the respondents this study can be ignored, most likely due to $500 \mathrm{kV}$ EHVT. This electromagnetic field sensation is generally experienced significantly by people living under $500 \mathrm{kV}$ EHVT. As stated by MAN, a carpenter:

"If the test pen touches the wire of clothesline, it must be on."

Similarly, DAS, a farmer, said: 
"If you bring an umbrella when rains under EHVT, the umbrella is pulled upward. In fact, body hair also stands." Another informant, SOUP, a housewife, often feels the sensation associated with $500 \mathrm{kV}$ EHVT, especially at night:

"If there is a fire, there are sprinkling and a loud hissing sound. I used to be scared, but now I am no longer afraid."

The sensation generated by the $500 \mathrm{kV}$ EHVT is justified by PR, a technician:

"In a cloudy especially rainy condition, umbrellas can be lifted up, body hair standing up. Test pen can be lit, but the flame is very weak. While the sound is hissing and like a spark, it's a normal symptom at $500 \mathrm{kV}$ EHVT. Not dangerous, really."

\section{Conclusion}

Based on the data obtained, the results of hypothesis testing and discussion of research results, can be drawn conclusion as follows. First, there is an effect of electromagnetic field exposure $500 \mathrm{kV}$ EHVT with electrical sensitivity events. Secondly, the magnitude of the risk of electrical sensitivity in populations residing under $500 \mathrm{kV}$ EHVT is 5.8 times higher than that of residents who do not reside under the $500 \mathrm{kV}$ EHVT. In general it can be concluded that electromagnetic field exposure derived from $500 \mathrm{kV}$ EHVT risks causing health disorders in the population, which is a set of symptoms of hypersensitivity known as electrical sensitivity, in the form of headache, dizziness and chronic fatigue syndrome. The results of this study indicate the effect of electromagnetic field exposure of $500 \mathrm{kV}$ on electrical sensitivity events and the risk to the exposed population of 5.8 times compared with those not exposed. Therefore, the results of this study have practical implications. Residents who live around the $500 \mathrm{kV}$ EHVT have risk for electrical sensitivity, although generally they do not know that the exposure can affect their health such as headaches, dizziness and chronic fatigue. They are only concerned about the possibility of broken wires and natural and physical phenomena from the effect of EHVTS $500 \mathrm{kV}$. Complaints that include electrical sensitivity are not only caused by the $500 \mathrm{kV}$ EHVT, but the results show that the magnitude of the risk of electrical sensitivity in populations residing under the $500 \mathrm{kV}$ EHVT is higher than that of residents who do not reside under the $500 \mathrm{kV}$ EHVT. Therefore, it is necessary for policy maker and national electricity company to familiriaze the populations living under the $500 \mathrm{kV}$ EHVT on possible effects resulting from the $500 \mathrm{kV}$ EHVT. Thus, the population can make prevention efforts in practical ways that enable themselves to minimize the exposure effect. Based on the conclusions and implications obtained from the results of the research, the following suggestions are proposed for various parties. Firstly, it is recommended for residents who live under the $500 \mathrm{kV}$ EHVT. Based on the result of the research, it can be concluded that there is an effect of electromagnetic field exposure EHVT $500 \mathrm{kV}$ with electrical sensitivity occurrence and the magnitude of the risk of electrical sensitivity in the population living under $500 \mathrm{kV}$ EHVT facilities 5.8 times bigger than the population not residing around EHVT $500 \mathrm{kV}$. The house or building around the electric transmission network has actually changed the potential field and lowered the electric field strength, due to the construction of the building with its walls and roofing that function as if it were a Faraday cage. It is recommended not to use the roof of the house from zinc or other materials that are conductive. For outdoors, the residents can plant trees in the yard or around the house to reduce the electric field strength.

\section{Competing Interests Statement}

The authors declare that there are no competing or potential conflicts of interest.

\section{References}

Adey, W. R. (1997). Brain tumor incidence in rats chronically exposed to frequency-modulated (FM) cellular phone fields. In Second World Congress for Electricity and Magnetism in Biology and Medicine (Vol. 109). Retrieved from https://ci.nii.ac.jp/naid/10000100762/.

Anies. (1997). Kontroversi Hasil Penelitian Pengaruh Medan Elektromagnetik terhadap Kesehatan (Controversy of Research Results on the Effect of Electromagnetic Fields on Health). Media Medika Indonesiana, 32(3), 137-140.

Anies. (1999). Kajian Lingkungan Saluran Udara Tegangan Ekstra Tinggi 500 kV Bandung Selatan - Ungaran (Environmental Assessment of $500 \mathrm{kV}$ Extra High Voltage Air Channels in South Bandung - Ungaran). Semarang: Center for Environmental Research, Diponegoro University Research Institute.

Arber, S. L., \& Lin, J. C. (1985). Microwave-induced changes in nerve cells: Effects of modulation and temperature. Bioelectromagnetics, 6(3), 257-270. https://doi.org/10.1002/bem.2250060306 
Dollins, A. B., Zhdanova, I. V., Wurtman, R. J., Lynch, H. J., \& Deng, M. H. (1994). Effect of inducing nocturnal serum melatonin concentrations in daytime on sleep, mood, body temperature, and performance. Proceedings of the National Academy of Sciences, 91(5), 1824-1828. Retrieved from https://www.ncbi.nlm.nih.gov/pmc/articles/PMC43256/

Esquifino, A. I., Villanua, M. A., Agrasal, C., Reiter, R. J., \& Tresguerres, J. A. F. (1989). Melatonin effects on prolactin secretion in pituitary-grafted female rats. Journal of endocrinological investigation, 12(3), 171-176. https://doi.org/10.1007/BF03349954

Frey, A. H. (1998). Headaches from cellular telephones: are they real and what are the implications?. Environmental health perspectives, 106(3), $101 . \quad$ Retrieved from https:/www.ncbi.nlm.nih.gov/pmc/articles/PMC1533043/

Graham, C., Cook, M. R., \& Riffle, D. W. (1997). Human melatonin during continuous magnetic field exposure. Bioelectromagnetics: Journal of the Bioelectromagnetics Society, The Society for Physical Regulation in Biology and Medicine, The European Bioelectromagnetics Association, 18(2), $166-171$. https://doi.org/10.1002/(SICI)1521-186X(1997)18:2<166::AID-BEM9>3.0.CO;2-0

Grant, L. (1997). Treatment survey results. Electrical Sensitivity News, 2(2), 1-5. Retrieved from http://www.tldp.com/issue/179/emf179.htm

Grant, L. (2003). Electrical Sensitivity as an Emerging Illness. Retrieved from http://www.tldp.com/info@townsendletter.com.

Hancı, H., Odacı, E., Kaya, H., Aliyazıcıoğlu, Y., Turan, İ., Demir, S., \& Çolakoğlu, S. (2013). The effect of prenatal exposure to $900-\mathrm{MHz}$ electromagnetic field on the 21-old-day rat testicle. Reproductive Toxicology, 42, 203-209. https://doi.org/10.1016/j.reprotox.2013.09.006

Hao, D., Yang, L., Chen, S., Tong, J., Tian, Y., Su, B., ... \& Zeng, Y. (2013). Effects of long-term electromagnetic field exposure on spatial learning and memory in rats. Neurological Sciences, 34(2), 157-164. https://doi.org/10.1007/s10072-012-0970-8

Hawkins, L. (1992). Seasonal affective disorders: the effects of light on human behaviour. Endeavour, 16(3), 122-127. https://doi.org/10.1016/0160-9327(92)90070-6

Indonesian Ministry of Mining and Energy. (1992). Regulation of the Minister of Mines and Energy Number 01.P/47/MPE/1992. Jakarta: Department of Mining and Energy.

International Non-ionizing Radiation Committee of the International Radiation Protection Association. (1990). Interim Guideline on Limits of Exposure to 50/60 Hz Electrical and Magnetic Fields. Health Physics 58(1), 113-122. Retrieved from https://www.ncbi.nlm.nih.gov/pubmed/2294069

Jonai, H., Villanueva, M. B. G., \& Yasuda, A. (1996). Cytokine profile of human peripheral blood mononuclear cells exposed to 50Hz EMF. Industrial health, 34(4), 359-368. https://doi.org/10.2486/indhealth.34.359

Kasnodihardjo. (1998). Persepsi Kebiasaan Penduduk dalam Kaitannya dengan Adanya Saluran Udara Tegangan Ekstra Tinggi di Daerah Cibinong dan Bekasi, Jawa Barat (Perceptions of Population Habits in Relation to the existence of Extra High Voltage Air Channels in Cibinong and Bekasi, West Java). Health Ecology Research Center, Research and Development Agency, Ministry of Health of the Republic of Indonesia.

Kato, M., Honma, K., Shigemitsu, T., \& Shiga, Y. (1994). Circularly polarized 50-Hz magnetic field exposure reduces pineal gland and blood melatonin concentrations of Long-Evans rats. Neuroscience Letters, 166(1), 59-62. https://doi.org/10.1016/0304-3940(94)90840-0

Kleinerman, R. A., Kaune, W. T., Hatch, E. E., Wacholder, S., Linet, M. S., Robison, L. L., ... \& Tarone, R. E. (2000). Are children living near high-voltage power lines at increased risk of acute lymphoblastic leukemia?. American Journal of Epidemiology, 151(5), 512-515. https://doi.org/10.1093/oxfordjournals.aje.a010237.

Kumar, S., Behari, J., \& Sisodia, R. (2013). Influence of electromagnetic fields on reproductive system of male rats. International journal of radiation biology, 89(3), 147-154. https://doi.org/10.3109/09553002.2013.741282

Kurniawan, R. (2017). Effect of environmental performance on environmental disclosures of manufacturing, mining and plantation companies listed in Indonesia stock exchange. Arthatama: Journal of Business Management and Accounting, 1(1), 6-17.

Lai, H. (1994). Neurological effects of radiofrequency electromagnetic radiation. In Advances in electromagnetic fields in living systems (pp. 27-80). Boston, MA: Springer.. 
Lewy, A. J., Ahmed, S., Jackson, J. M. L., \& Sack, R. L. (1992). Melatonin shifts human orcadian rhythms according to a phase-response curve. Chronobiology international, 9(5), $380-392$. https://doi.org/10.3109/07420529209064550

Linet, M. S., Hatch, E. E., Kleinerman, R. A., Robison, L. L., Kaune, W. T., Friedman, D. R., ... \& Wacholder, S. (1997). Residential exposure to magnetic fields and acute lymphoblastic leukemia in children. New England journal of medicine, 337(1), 1-8. https://doi.org/10.1056/NEJM199707033370101

London, S. J., Thomas, D. C., Bowman, J. D., Sobel, E., Cheng, T. C., \& Peters, J. M. (1991). Exposure to residential electric and magnetic fields and risk of childhood leukemia. American journal of epidemiology, 134(9), 923-937. https://doi.org/10.1093/oxfordjournals.aje.a116176

LPM-ITB \& FKUI. (1997). Penelitian Pengaruh Medan Listrik dan Medan Magnet Saluran Udara Tegangan Tinggi dan Saluran Udara Tegangan Ekstra Tinggi terhadap Kesehatan Manusia: Executive Summary Aspek Kesehatan. Jakarta: LPM-ITB and FKUI.

Maziarz, A., Kocan, B., Bester, M., Budzik, S., Cholewa, M., Ochiya, T., \& Banas, A. (2016). How electromagnetic fields can influence adult stem cells: positive and negative impacts. Stem cell research \& therapy, 7(1), 54. https://doi.org/10.1186/s13287-016-0312-5

Mueller, C. H., Krueger, H., \& Schierz, C. (2002). Project NEMESIS: perception of a 50 Hz electric and magnetic field at low intensities (laboratory experiment). Bioelectromagnetics, 23(1), 26-36. https://doi.org/10.1002/bem.95

National Sleep Foundation. (2004). What is Melatonin?. Retrieved from http://www.sleepfoundation.org/publications/melatoninthefact.html.

Oftedal, G., Wilen, J., Sandström, M., \& Mild, K. H. (2000). Symptoms experienced in connection with mobile phone use. Occupational medicine, 50(4), 237-245. https://doi.org/10.1093/occmed/50.4.237

Petrie, K., Dawson, A. G., Thompson, L., \& Brook, R. (1993). A double-blind trial of melatonin as a treatment for jet lag in international cabin crew. Biological psychiatry, 33(7), 526-530. https://doi.org/10.1016/0006-3223(93)90007-Z

Poole, C., Kavet, R., Funch, D. P., Donelan, K., Charry, J. M., \& Dreyer, N. A. (1993). Depressive symptoms and headaches in relation to proximity of residence to an alternating-current transmission line right-of-way. American Journal of Epidemiology, 137(3), 318-330. https://doi.org/10.1093/oxfordjournals.aje.a116679

Real, W. J., Pan, Y., Fenyves, E. J., Sujisawa, I., Suyama, H., Samadi, N., \& Ross, G. H. (1991). Electromagnetic field sensitivity. Journal of Bioelectricity, 10(1-2), 241-256. https://doi.org/10.3109/15368379109031410

Reiter, R. J. (1997). Melatonin aspects of exposure to low frequency electric and magnetic fields. In Lin, J. C. (Ed.), Advances in electromagnetic fields in living systems (1-28). London: Plenum Press.

Sandström, M., Wilen, J., Hansson Mild, K., \& Oftedal, G. (2001). Mobile phone use and subjective symptoms. Comparison of symptoms experienced by users of analogue and digital mobile phones. Occupational Medicine, 51(1), 25-35. https://doi.org/10.1093/occmed/51.1.25

Sandyk, R., \& Derpapas, K. (1993). Magnetic fields normalize visual evoked potentials and brainstem auditory evoked potentials in multiple sclerosis. International journal of neuroscience, 68(3-4), 241-253. https://doi.org/10.3109/00207459308994279

Savitz, D. A., Pearce, N., \& Poole, C. (1993). Update on methodological issues in the epidemiology of electromagnetic fields and cancer. Epidemiologic reviews, 15(2), 558-566.

Singh, S., \& Kapoor, N. (2014). Health implications of electromagnetic fields, mechanisms of action, and research needs. Advances in biology, 2014, 1-24. http://dx.doi.org/10.1155/2014/198609

Tumiran, T. (2005). Keberadaan SUTET $500 \mathrm{kV}$ bagi jaminan suplai listrik Jamali serta paparan medan listrik dan medan magnetnya. The paper presented at the National Seminar on the role of $500 \mathrm{kV}$ EHVT in ensuring the Java-Madura-Bali electricity supply and its various aspects, Yogyakarta, August 11, 2005, Electrical Engineering Department, Gadjah Mada University. Retrieved from https://repository.ugm.ac.id/digitasi/download.php?file=2892_3

Wertheimer, N., \& Leeper, E. D. (1979). Electrical wiring configurations and childhood cancer. American journal of epidemiology, 109(3), 273-284. https://doi.org/10.1093/oxfordjournals.aje.a112681

World Health Organization [WHO]. (2007). Electromagnetic fields and public health: Exposure to extremely low 
frequency fields. Retrieved from http://www.who.int/peh-emf/publications/facts/fs322/en/

World Health Organization [WHO]. (1987). Magnetic Fields. Geneva: Environments Health Criteria 69.

Zhang, Y., Liu, X., Zhang, J., \& Li, N. (2015). Short-term effects of extremely low frequency electromagnetic fields exposure on Alzheimer's disease in rats. International journal of radiation biology, 91(1), 28-34. https://doi.org/10.3109/09553002.2014.954058

Zhdanova, I. V., Wurtman, R. J., Lynch, H. J., Ives, J. R., Dollins, A. B., Morabito, C., ... \& Schomer, D. L. (1995). Sleep-inducing effects of low doses of melatonin ingested in the evening. Clinical Pharmacology \& Therapeutics, 57(5), 552-558. https://doi.org/10.1016/0009-9236(95)90040-3

Zordan, M. A., \& Kyriacou, C. P. (2005). The circadian clock in mammals. The journal of headache and pain, 6(5), 424-424. https://doi.org/10.1007/s10194-005-0242-6

\section{Copyrights}

Copyright for this article is retained by the author(s), with first publication rights granted to the journal.

This is an open-access article distributed under the terms and conditions of the Creative Commons Attribution license (http://creativecommons.org/licenses/by/4.0/). 